\title{
Productivity and seasonal changes in selected reef areas in the Gulf of Aqaba (Red Sea)
}

\author{
H. Mergner \& A. Svoboda \\ Rubr-Universität Bochum, Lebrstubl für Spezielle Zoologie; \\ Bochum, Federal Republic of Germany
}

\begin{abstract}
In the first detailed ecological description of a fringing reef (Mergner \& Schuhmacher, 1974) two parts of the reefs south of Aqaba (Red Sea) were considered. These investigations have been extended to an eco-functional analysis of the seasonal fluctuations of algal growth, sessile and mobile fauna, and productivity of biocoenoses. Two test areas were observed from October 1975 to June 1976; one is situated in the reef lagoon with strong influences of temperature, light intensity, currents and sedimentation; the other, in the middle fore reef with reduced illumination, water movement and sedimentation. A precise quantitative analysis of the stock of benthic reef algae was made by elaborating the percentual coverage ratio of each species within a well-defined reef area. At the beginning of the year, the algal vegetation with 23 species appeared in different successions, abundance and dominance. The phytal disappeared, in several steps, from early spring to late summer (e.g. due to grazing, epiphytes, loss of algal dyes). Such rhythms in phytal population dynamics lead to fundamental changes in mobile fauna living conditions. Molluses and echinoderms serve as good examples (about 140 species were identified). The increase in some species, caused by rapid algal growth is remarkable, as is the high percentage of juvenile individuals. Grazing by sea-urchins constitutes an important factor controlling seasonal changes in benthic algae. Some soft corals, especially xeniids, and some stony corals, mainly Stylophora pistillata, undergo similar seasonal fluctuations within the same period. The fluctuations are partly characterized (1) by the disappearance of colonies caused by feeding and natural collapse following the breeding season, and (2) by recolonization or new settling. During $24 \mathrm{~h}$ in situ measurements, soft and stony corals and other coelenterates inhabited by zooxanthellae show a conspicuous surplus in $\mathrm{O}_{2}$ production down to $40 \mathrm{~m}$ depth. In all species examined, maximum $\mathrm{O}_{2}$ consumption and productivity per unit dry weight are found below $5 \mathrm{~m}$, with a decrease of 25 to $50 \%$ at $1 \mathrm{~m}$ depth. $\mathrm{O}_{2}$ consumption during the period of photosynthesis is 20 to $30 \%$ higher than during the night. There is a slight decrease in $\mathrm{O}_{2}$ production after reaching morning light saturation values; this might be caused by the storage of metabolic products. Xeniids show a stepwise increase in oxygen output, caused by diurnal rhythmic colony contraction.
\end{abstract}

\section{INTRODUCTION AND PROBLEMS}

The first detailed ecological analysis of a fringing reef was done at two places on the reefs south of Aqaba (Red Sea) (Mergner \& Schuhmacher, 1974). The most important abiotic parameters for single reef zones and their effects on fauna and flora were determined qualitatively, but not yet quantitatively. The numerous biotic 
interactions of reef inhabitants, regarding structure and biocoenosis of different reef landscapes, could only be worked out summarily. Therefore it was the goal of the following investigations to advance from a description of the biocoenosis to an ecofunctional analysis of autecological and synecological relationships.

We have selected several reef areas, characteristically limited in space, and carefully mapped their structures and substrates; major fauna and flora elements were determined quantitatively, and the most important ecological factors measured for a defined period. In this way, we could analyse seasonal changes in the structure of settlements, elicited both by exogenous factors and endogenous population dynamics. Because of the expected rapid development of the phytal and the corals at the beginning of the year and their influences on the mobile fauna, the investigations were conducted during winter; measurements of productivity contributed by the reef inhabitants to the productivity of their biotopes were added.

Therefore, cnidarians containing symbiotic zooxanthellae were studied. Since Odum \& Odum (1955) and Johannes et al. (1970) proved that there is not enough plankton in the tropical oceans for supplying food for reef corals and their inhabitants, the role of corals as primary producers was investigated by several authors. Kanwisher \& Wainwright (1967), Roffmann (1968) and Franzisket (1969) calculated from laboratory experiments on the respiration and $\mathrm{O}_{2}$ production of corals that corals may not only live autotrophically, i. e. on carbohydrates released by their symbiotic zooxanthellae (Muscatine \& Hand, 1958; Lewis \& Smith, 1971) but produce a surplus in organic matter. Since in situ studies on a 24 h cycle had not been performed previously, underwater experiments were included in the investigations in order to explore the importance of the immense stock of soft and stony corals as plankton feeders and primary producers.

Selection and mapping of the test areas, of the fauna and flora and of their seasonal fluctuations, as well as the recording of important abiotic and biotic factors were carried out by Mergner, the measurements on P/R-ratio in corals and on light intensity, by Sroboda.

\section{MATERIAL AND METHODS}

The same areas, previously investigated by Mergner \& Schuhmacher (1974), have been studied: two comparable test areas of $5 \times 5 \mathrm{~m}$. One area $(\mathrm{L}-1)$ is situated in the shallow, well illuminated and tide-influenced lagoon of the fringing reef which is characterized by vigorous currents, the other area (U-7) in the moderately illuminated, tide-independent middle fore reef of the coastal fringing reef, which is characterized by weak currents (Fig. 1). Most of the measurements of the parameters, the collecting of fauna and flora, and the recording of seasonal changes were done in $\mathrm{L}-1$; in U-7, only a few measurements of abiotic parameters and analysis of the stock of the sessile fauna could be performed. Cand. rer. nat. M. Mastaller and F. Nobbe conducted special ecological investigations in separate test areas in the same parts of the reef.

Air temperatures (maximum, minimum, average month') and the temperatures of the surface water from October 1975 to May 1976 were measured by Nobbe and 
Mergner; in addition, the direction of water currents in $\mathrm{L}-1$ were observed at the surface and close to the bottom. A total of 176 fluorescin samples were obtained at rising and falling tides, and during comparable wind directions and velocities. Salinity, oxygen content and $\mathrm{pH}$ could only be measured occasionally.
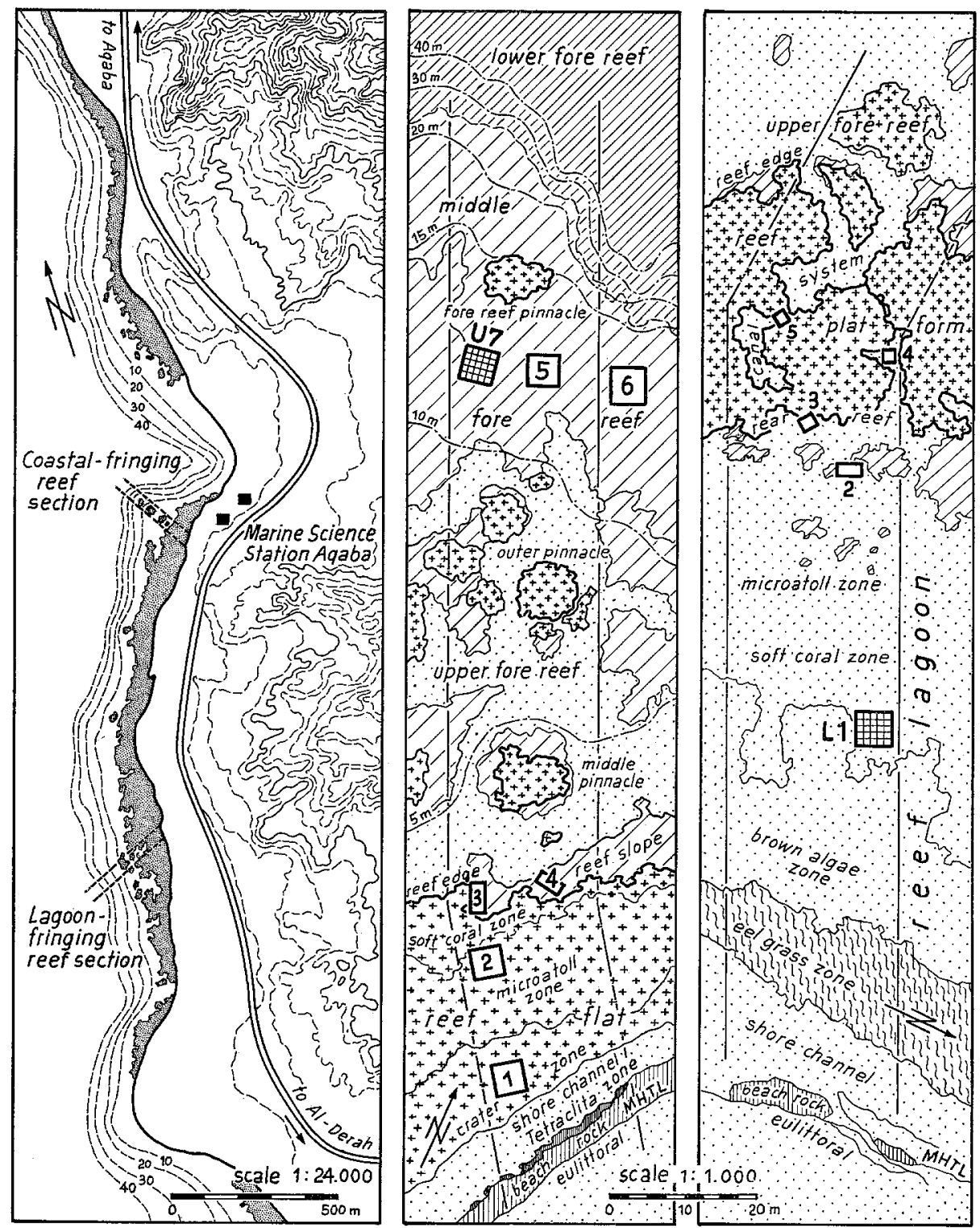

Yig. 1: Reef area of Marine Science Station Aqaba, $6 \mathrm{~km}$ south of Aqaba harbour (left), with two transects studied by Mergner \&x Schuhmacher (1974), the first through coastal fringing reef (centre), the second through the lagoon fringing reef (right) with positions of investigated test squares, among them $\mathrm{U}-7$ in middle fore-reef and $\mathrm{L}-1$ in lagoon 
As nearly as possible, the fauna and flora at $\mathrm{L}-1$ and their changes were recorded quantitatively during the winter period $1975 / 76$. The species concerned - at least 23 algae and 140 animals - will be listed in a later publication, together with data on distribution within the test area and on correlation to the substrate.

At U-7, only species distribution, species diversity and abundance of the coral fauna were determined; neither did the algal growth play an important role in this area nor did it cause any change in species occurrence or number of individuals. The number of species however, would certainly increase if the endolithic fauna would be included; however, by cracking the coral-rock structures, the whole test areas would be destroyed.

In situ measurements on $\mathrm{O}_{2}$ production and respiration were performed on the hydrocoral Millepora dichotoma, the scyphomedusa Cassiopeia andromeda, the zoantharian Palythoa mammillata, the alcyonarians Lithophyton arboreum, Heteroxenia ghardaqensis, Xenia membranacea, Xenia macrospiculata and the hermatypic corals Fungia scutaria, Acropora variabilis, Stylophora pistillata, Favia pallida and Goniastrea pectinata.

Between depths of 1 to $40 \mathrm{~m}$, individuals were chiseled off and inserted in 1.41 bell jars. Oxygen and temperature were measured by a self-contained pressure-proof recording system with two temperature-compensated polarographic electrodes, inserted into two closed circuits connected to the stirred bell jars (Fig. 5). Light recordings were made by two calibrated silicone cells connected to a second selfcontained and pressure-proof recording unit. The spectral light distribution at different depth was measured by a separate calibrated silicone cell covered by six calibrated interference colour filters mounted on a sledge. After fixing the individuals collected in $10 \%$ formaline, diluting the skeleton in $10 \% \mathrm{HCl}$, rinsing, drying at $105^{\circ} \mathrm{C}$, and burning to ash at $1000^{\circ} \mathrm{C}$, the biomass was determined in terms of ash-free dry weight.

The light recording system used was developed by $\mathrm{R}$. Machan, the oxygen recording system by $\mathrm{R}$. Machan and A. Svoboda at the University of Vienna (Austria); the spectral filter photometer, by K. Dietzel, Krefeld (F. R. Germany).

\section{RESULTS AND CONCLUSIONS}

The results presented here concentrate on the initial situation in area $\mathrm{L}-1$, the seasonal fluctuations observed, and the first results of the increase in productivity. A detailed account of all results obtained will be published later.

\section{Initial situation in $\mathrm{L}-1$}

The area investigated by Mergner \& Schuhmacher (1974) at the lagoon fringing reef is a transect stripe which runs from ENE to WSW (Fig. 2). L-1 has a distance of about $2 \mathrm{~m}$ to the right boundary of this stripe and is located 56.5 to $61.5 \mathrm{~m}$ far off the MTL of the eulittoral (Fig. 1). This means that L-1 belongs to both biophysiographi- 


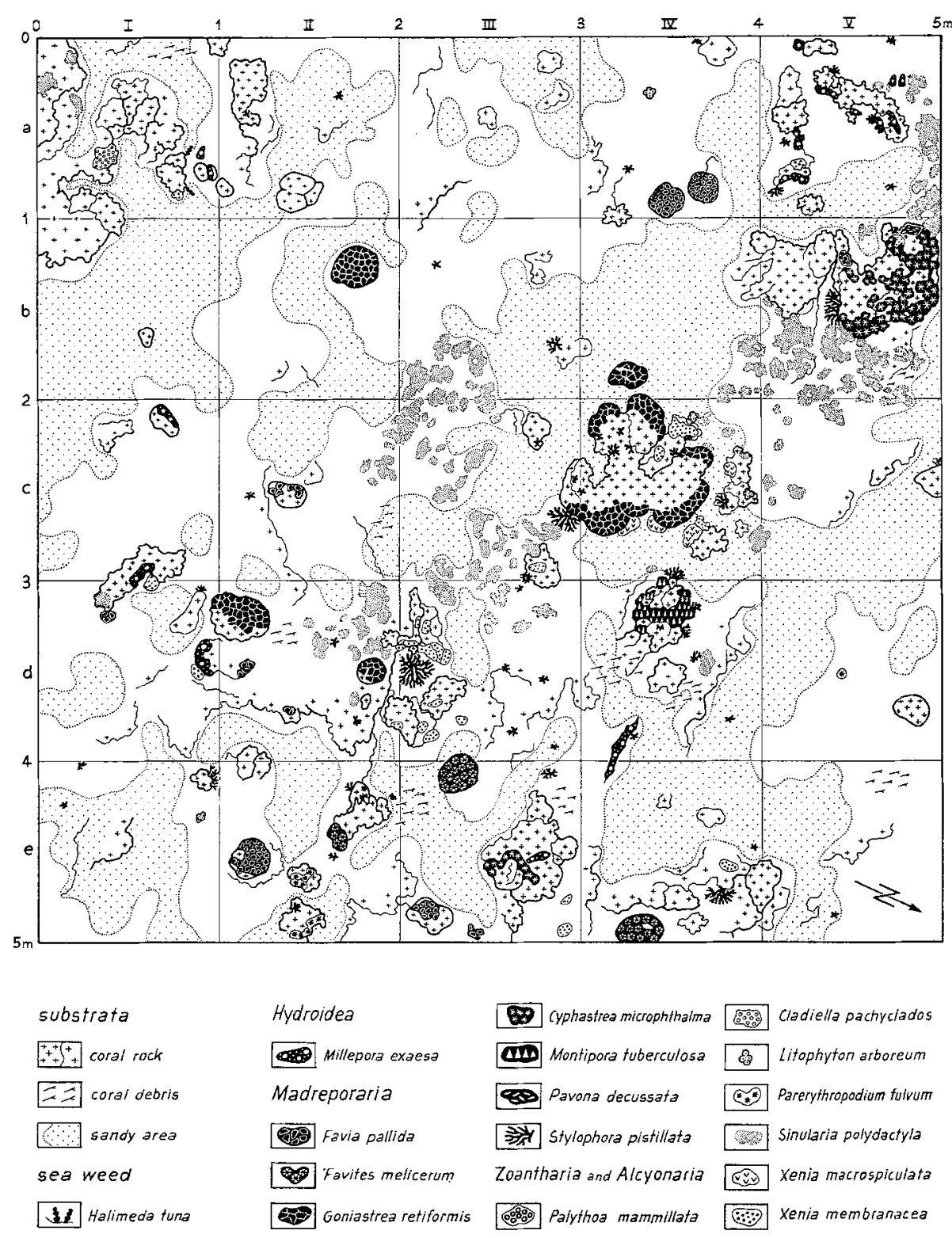

Fig. 2: Start situation of the test area $\mathrm{L}-1$ in October, 1975 with analysis of structures and settlement

cal zones of the phytal zone, i.e. the Sargassum dentifolium- and the Stypopodium zonale zone.

In $\mathrm{L}-1$, the bottom of the lagoon, mostly covered by fine coral mould, consists of partly appearing coral rock slabs which are remains of the former reef platform 
destroyed by erosion. Between the slabs, which show a moderate declination to the open sea, the troughs are covered by a mixture of fine organogenic and mineral sand. Only two bigger, eroded coral heads of $75 \mathrm{~cm}$ in diameter with living corals at the current exposed sides and big basal cavities raise from the bottom of the lagoon. Furthermore, there are small, dead coral remains with secondary colonization by different crusty stony corals and Millepora exaesa, about one dozen spherical colonies of Favia, approximately 60 living stocks of Stylophora pistillata of different sizes and a number of dead coral stumps in different stages of preservation. The structural aspect of this typical part of the lagoon is completed by several species of soft corals which settle on the slabs, by small areas of gathered coral rubble and many decayed algae. The only living algae at $\mathrm{L}-1$, in addition to small areas covered by crusts of Lithothamnion and Lithophyllum, were two stems of Halimeda tuna. This area, appearently more or less uniform in terms of its structures and substrates, includes a rich fauna (Mergner \& Schuhmacher, 1974 p. 291 and p. 307).

Only a partial analysis of some groups of the mobile fauna in October 1975 was possible so as not to affect the initial condition of the site. Without further disturbing the test area large numbers of individuals could be noted. Very high abundancies were recorded, for example, of some echinoderms (i. e. 49 individuals of Echinometra mathaei, 9 of Diadema setosum, 8 of Linckia multiflora and 6 of Halodeima spp.).

\section{Seasonal colonization fluctuations in $\mathrm{L}-1$}

During the winter $1975 / 76$, no strong southern storms occurred in the Gulf of Aqaba; therefore, only minimal structural changes were observed when the studies began again at the end of January 1976. Some smaller coral remains, not sufficiently fixed in the bottom, were found about $50 \mathrm{~cm}$ away from their original places, others were transported into the test area; in both cases no effects on the fauna could be established. The number and the composition of the species, however, revealed particulary conspicuous changes, regarding the soft coral Xenia sp., the stony coral Stylophora pistillata and some molluscs and echinoderms. Therefore, all these organisms will be described in more detail than the others.

\section{Algal cover}

During the period of our observation, the most conspicuous changes occurred in the phytal of the reef lagoon. They involved a rapid increase in the algal stock and successions as well as fluctuations in the dominance of several species. The following observations (Mastaller \& Nobbe) refer to algal populations in the test area L-1 (Figs. $3 \& 4$ ).

The initial situation in October 1975 was characterized by the almost complete absence of algae within the test area (average surface temperature $24^{\circ} \mathrm{C}$ ). The first algal population to commence growing was Padina pavonica at the beginning of December, forming patches of about $5 \mathrm{~cm}$ height that were present until the end of 


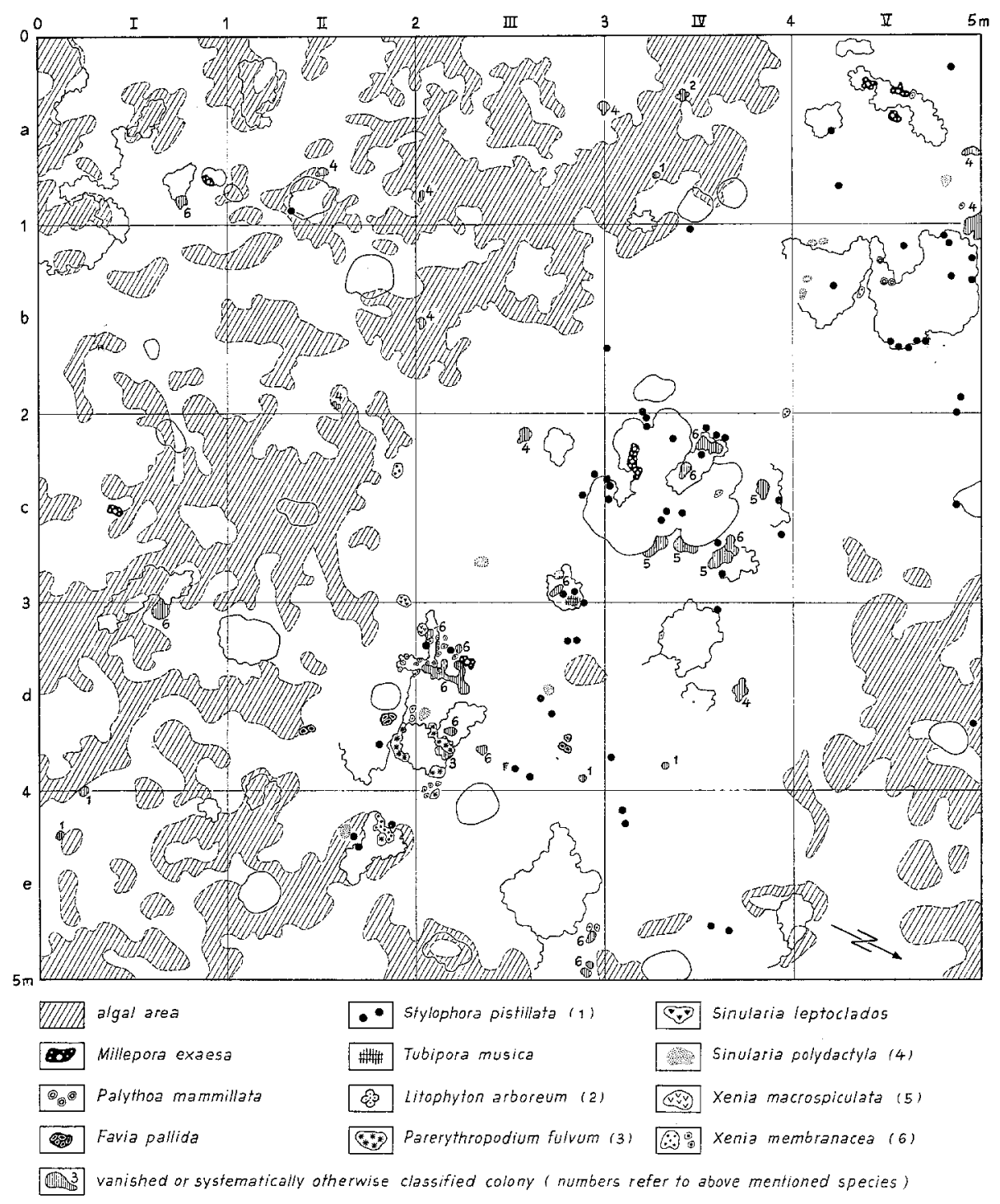

Fig. 3: Seasonal changes in the test area L-1 from October, 1975 until February, 1976 concerning the disappearance, recolonization and new settlement of benthic algae, soft and stony corals

January 1976. Two dominating species of brown algae appeared in the middle of December $\left(22^{\circ} \mathrm{C}\right)$ : Sargassum dentifolium formed expanded lawns and Cystoseira myrica was comprised mostly of dense tufts. Colpomenia sinuosa appeared at the end of January $1976\left(21^{\circ} \mathrm{C}\right)$ and its vesicular thalli disappeared by the end of March $\left(23^{\circ} \mathrm{C}\right)$ and early April, when Stypodium zonale began growing to cover vast areas of 
the bare coral slabs, Tubinaria elatensis began to dominate and the red alga Liagora turneri appeared. During this time the formerly predominant brown algae continued decaying. Small areas of Cystoseira myrica still remained at the end of February. Sargassum dentifolium, after an enormous culmination in February and March, showed distinctly reduced thalli in May and was increasingly succeeded by $S$. zonale.

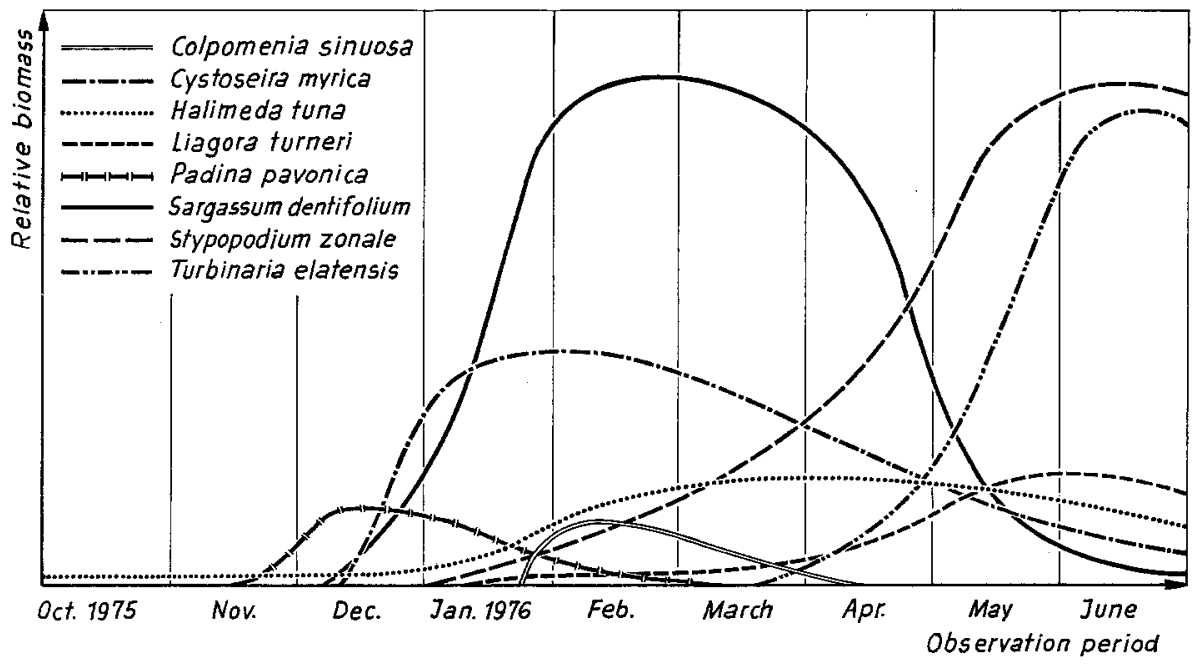

Fig. 4: Preliminary analysis of the development of the algal stock in the test area $\mathrm{L}-1$ during the observation period $1975 / 76$. Seasonal fluctuations and relative biomass of some important algal species

The trunks of this algae and others seemed to survive the summer and fall and came into leaf again in the next vegetation period. Evaluations of underwater pictures of the same test-square sub-areas showed that the trunks from October 1975 could be located exactly on the photos of February 1976 when covered by thalli of the species concerned. In L-1 $\left(25 \mathrm{~m}^{2}\right)$ not less than 23 species of algae were noted; 15 had already been recorded at the beginning of February. $T$. elatensis appeared later; five filamentous species which settled on dead coral heads are supplementary. A detailed distribution pattern of the percentual covering of the area by each species will be published later; the algal cover $(24.5 \%)$ is demonstrated in Figure 3. It can be seen that Sargassum dentifolium emerges with $74.0 \%$ as the characteristic species (Table 1).

Looking for reasons for these conspicuous successions and fluctuation of dominances, both abiotic and biotic interactions have to be respected. During the investigation period water temperatures remained between $24^{\circ} \mathrm{C}$ in October and June, and $21^{\circ} \mathrm{C}$ from January to March. Salinity, $\mathrm{O}_{2}$ content and $\mathrm{pH}$ showed only slight variations. Despite the low winter orbit of the sun, even occasional cloudiness (mostly lower than 3/10), insolation rate and diurnal duration of sunshine appear to be sufficient for a rich growth of algal vegetation on the white coral mould. The prevailing northwinds $(80 \%)$ of mainly 3-4 $\mathrm{Bft}$ cause average wave amplitudes of 0.3 to $0.5 \mathrm{~m}$. Together with well marked tidal currents these wave actions prevent the 
Table 1

Algal coverage expressed as percentage of the total test area at the beginning of February, 1976 in L-1

\begin{tabular}{|lcc|}
\hline Algal species & Coverage* & \% of total algal cover** \\
\hline Sargassum dentifolium & 18.89 & 73.84 \\
Stypopodium zonale & 2.18 & 8.55 \\
Dictyota indica & 1.92 & 7.52 \\
Halimeda tuna & 0.69 & 2.71 \\
Liagora turneri & 0.67 & 2.64 \\
Cystoseira myrica & 0.43 & 1.68 \\
Lithothamnion sp. & 0.23 & 0.93 \\
Hydroclatbrus clatbratus & 0.15 & 0.60 \\
Padina pavonica & 0.09 & 0.35 \\
Galaxaura lepidescens & 0.09 & 0.36 \\
Colpomenia sinuosa & 0.06 & 0.26 \\
Litbophyllum (fruticulosum?) & 0.05 & 0.22 \\
Codium (arabicum?) & 0.04 & 0.19 \\
Lyngbya aestuarii & 0.01 & 0.06 \\
Ulva lactuca & 0.01 & 0.02 \\
Total algal coverage (\%) & 25.51 & 100.00 \\
Algal free area (\%) & 74.49 & - \\
* Coverage by algae in percentage of the total test area. & \\
** Percentual portion of each algal species in the total algal cover. \\
\hline
\end{tabular}

stratification of the water body in the reef lagoon and therefore avoid the negative effects of extreme temperatures and desiccation on the phytal at low tides.

It is difficult to estimate how the effects of the mostly trifling changes of single factors can elicit fluctuations in the population dynamics of benthic algae. Therefore parallel but differentiated studies should be done to measure the course of nutrient content in surface waters. There was a distinct increase in phosphate-dust pollution during our study period, after the local phosphate-railway and the loading facilities at the port of Aqaba were established. Emphasis is given that additional effects of eutrophication may be induced. Nevertheless we should take into consideration the coincidence of numerous (mostly trifling) changes of abiotic factors together with a probable increase of phosphate and the specific endogenous growth rates and biotic interactions as triggers of population dynamics. Such biotic interactions or reactions are overgrazing, epiphytes, affections due to phytoplancton blooms (for example reduction of transmittance and increase in sedimentation rate) and loss of assimilates caused by stress situations. Mastaller (personal communication) has proved overgrazing by herbivorous feeders as Diadema setosum and Echinometra mathaei: cage experiments in the reef lagoon showed an immediate disappearence of algae after including these animals; in exclusion experiments, algal development in the cages could be observed. Moreover, Mergner found almost no dendroid algae, which are typical for hard substrates in the vicinity of the two big coral rock heads in the test area where the basal cavities were inhabited by Diadema setosum (October 1975: February 7, 1976: 16 specimens). This underlines the importance of Diadema setosum as a controlling factor of algal vegetation. 
Moreover, negative influences are thought to be caused by the coverage of the older thalli with epiphytes acting as additional traps of fine coral mould followed by all phenomena of light reduction (changes in the light absorbance, reduction of light input and of the photosynthetic activities), and decrease of oxygen. Thus an intensive overgrowing of decaying thalli of Sargassum dentifolium by a flamentous ectocarpacean was observed at the end of March 1976 (Mastaller, personal communication). Further studies should explain if the loss of brownish dyes by the large brown algae, as was observed by Mastaller several times after extreme low tides, at pronounced warming of the lagoon water and weak currents, are normal emissions of algal assimilates or if they are damage due to the stress situation. Similar postulations should be made regarding the effects of the phytoplankton bloom in spring 1976 which reduced the normal visibility from 20 to $5 \mathrm{~m}$. It is emphasized that biotic interactions have the same effects on succession, abundance and dominance of the algal species as some chemical and physical factors.

Thus the first time a precise quantitative analysis of the stock of benthic algae was made by elaborating on the percentual covering ratio of each species within a well defined test area. Simultaneously, the seasonal changes of abundance, dominance and succession of the species involved were described, and their effects and causes were discussed. The results of both studies demonstrate the importance of the development of phytal for the seasonal increase of total productivity. Since soft and stony corals inhabited by symbiotic zooxanthellae are greatly involved in this process, their fluctuations are summarized. They exert, together with the algae, fundamental influences on mobile fauna.

\section{Sof t corals}

The seasonal fluctuation of soft corals in L-1 is less striking than the appearance and succession of algae. The soft corals considered in this paper are alcyonarians (7 species) and one species of zoantharians (Palythoa mammillata). The most important changes during the winter period 1975/76 were the disappearance of colonies and new settlements. The most conspicious examples of this are the xeniids; at least two species were found in the test area, i. e. Xenia macrospiculata and Xenia membranacea. By comparing the analysis of autumn 1975 with that of February 1976, the disappearance of almost all colonies of xeniids which were attached to big coral heads and their environments is striking. Feeding by inhabitants of the neighbouring coral head area (Diadema setosum, Echinometra mathaei, Dascyllus trimaculatus or Chaetodon chrysurus) is suggested, however, the proof is missing. A further reason could be that these pluriannual species suffer a natural collapse regulated endogenously after their breeding (Gohar, 1940: in Heteroxenia fuscescens from March till September, in Xenia macrospiculata till October). This is emphasized by the long period of observations and the numerous new colonies (diameter: $1-3 \mathrm{~cm}$ ) which appeared since October (Fig. 3).

Few changes could be noticed in the numerous colonies of Sinularia polydactyla. About $10 \%$ of their clusters (more than 100 of different sizes and shapes) disappeared 
until spring 1976, but approximately the same number was then added. One of four small colonies of Lithopbyton arboreum was detached; the one colony of Cladiella pachyclados remained at its original size. Only the crustlike layers of Parerytbropodium fulvum had notably increased during the winter. Remarkable was the first settlement of a small, since then dead, colony of Tubipora musica in the test area and the appearance of tiny new colonies of Palythoa mammillata which consisted of a single polyp that settled down in close neighbourhood to the "mother" colony. A detailed analysis of the changes of the soft corals and data on the areal cover will be published separately.

\section{Hydro-and stony corals}

All colonies of hermatypic corals, partly plane and crusty, partly massively rounded, and the hydrocoral Millepora exaesa (Fig. 2) which were noted in October 1975 at $\mathrm{L}-1$, could be found again in springtime. Additional observations were made on small areas of $M$. exaesa, but it is possible that they were covered by coral mould in October and could not be analysed. However, during the study of seasonal changes of stony corals in February 1976, 5 very small colonies of Favia pallida were detected which apparently were new settlers; three of them had one polyp, one colony had two and the other had three polyps (Fig. 3).

In contrast to these more or less trifling changes of the colonization of the spherically growing stony corals during the winter period 1975 to 1976 , Stylophora pistillata showed a remarkable increase; its breeding season ranges from fall until summertime. During the analysis of October 1975, 60 colonies ranging from 1.5 to $23 \mathrm{~cm}$ in diameter were counted and mapped, among them were some found loose on the sand. Repeated mapping in February 1976 showed that there were 65 new settled colonies. Most of them were tiny colonies (55) from 0.3 to $2.5 \mathrm{~cm}$ in diameter. It cannot be determined if the other 10 larger colonies were broken parts of a colony that fixed themselves again, which is possible under suitable conditions. $80 \%$ of all juvenile colonies were found on algal-free, hard substrate, close to the few larger colonies (diameter more than $10 \mathrm{~cm}$ ), whereas only 5 older and 4 very small colonies were detected within the algal lawn. The results of a precise analysis of the seasonal fluctuations of Stylophora pistillata will be published in a separate paper.

\section{Mobile fauna}

In our October 1975 survey, certain species or individual specimens (Foraminifera, Porifera, Turbellaria, Polychaeta and Crustacea) were not observed to avoid disturbances in their biotopes. Others were collected only in spring 1976 and are therefore not suitable for seasonal comparisons. A list of all species will be published in another paper. 


\section{Mollusca}

In autumn 1975 the gastropods and bivalves were mapped only to an extent that did not affect their biotops too much; in February 1976 Mastaller made extensive collections and observations on this topic. Thereby the bottom was searched down to a depth of $10 \mathrm{~cm}$. A total of 58 species of molluscs and 460 specimens were noted in L-1. A list of all species will be published together with an extended analysis of the correlations between substrate and species distribution pattern. Some further information on molluscs is expected from what Mastaller obtained in his studies on stomach content analysis of several grazers on the reef platform and in the lagoon. There is no doubt that a great number of the species and specimens of molluscs observed, moved into L-1 when phytal conditions improved there. This is emphasized by the significant difference between subsamples of molluscs in October and February.

\section{Echinodermata}

In October 1975 the distribution and number of the more frequent echinoderms in $\mathrm{L}-1$ were recorded without perturbance of the biotope providing valid possibilities of comparison between Echinometra mathaei, Diadema setosum, Linckia multiflora and Halodeima atra in November 1975 and February 1976. There could also be noted changes in abundances of echinoderms and their dependence on algal vegetation. During quantitative studies in February 1976 we found 191 specimens of 13 species; only some ophiurids hidden in crevices could not be completely collected. Halodeima atra was found during the day on the sandy grass bottoms and between Sargassum dentifolium. All other echinoderms were concentrated in the few hiding places in this area: Diadema setosum retracted into the spacious cavities of the coral heads, Echinometra mathaei into the interstitial gaps of the branches of living and dead Stylophora pistillata and into small openings in the bottom under the coral rock ruins, Linckia multiflora lived under rubble and slabs, and species of Ophiocoma in holes, crevices and similar cavities.

Among the 13 echinoderm species found at L-1, there were in February 1976, 129 specimens of Echinometra mathaei (in autumn only 49), 17 Diadema setosum (9), 5 Halodeima atra and 4 Halodeima sp. (6 together) and 16 Linckia multiflora (8). Not only the increase in some of the species is of interest, probably caused by changed living conditions due to algal development at the beginning of the year, but also the high percentage of juvenile specimens. Among the 129 individuals of Echinometra mathaei found in February 1976, there were 43 juveniles (in October none); among 17 Diadema setosum, 7 juveniles (none); among 16 Linckia multiflora, 6 juveniles (none); and among 9 Halodeima sp. 4 juveniles (none).

Concerning the influence of echinoderms on reef dynamics, the observations and the cage experiments of Mastaller have already been mentioned. These results show grazing sea-urchins, especially Diadema setosum, as an important controlling factor on the seasonal changes of benthic algal communities. 


\section{Pisces}

Because of the lack of suitable hiding places for fish there are very few permanent inhabitants of the test area: One adult and one juvenile specimen of Dascyllus trimaculatus and one Meiacanthus nigrolineatus were found under the big coral heads; one Hemibalistes chrysoptera and one Amphiprion bicinctus living in the neighbouring areas, included the test area in their territory. Several predator species and Chaetodon chrysurus were the only species commonly found in the test area. As mentioned before fish grazing could exert influence on the growth of algae and soft corals, but no detailed observations were made.

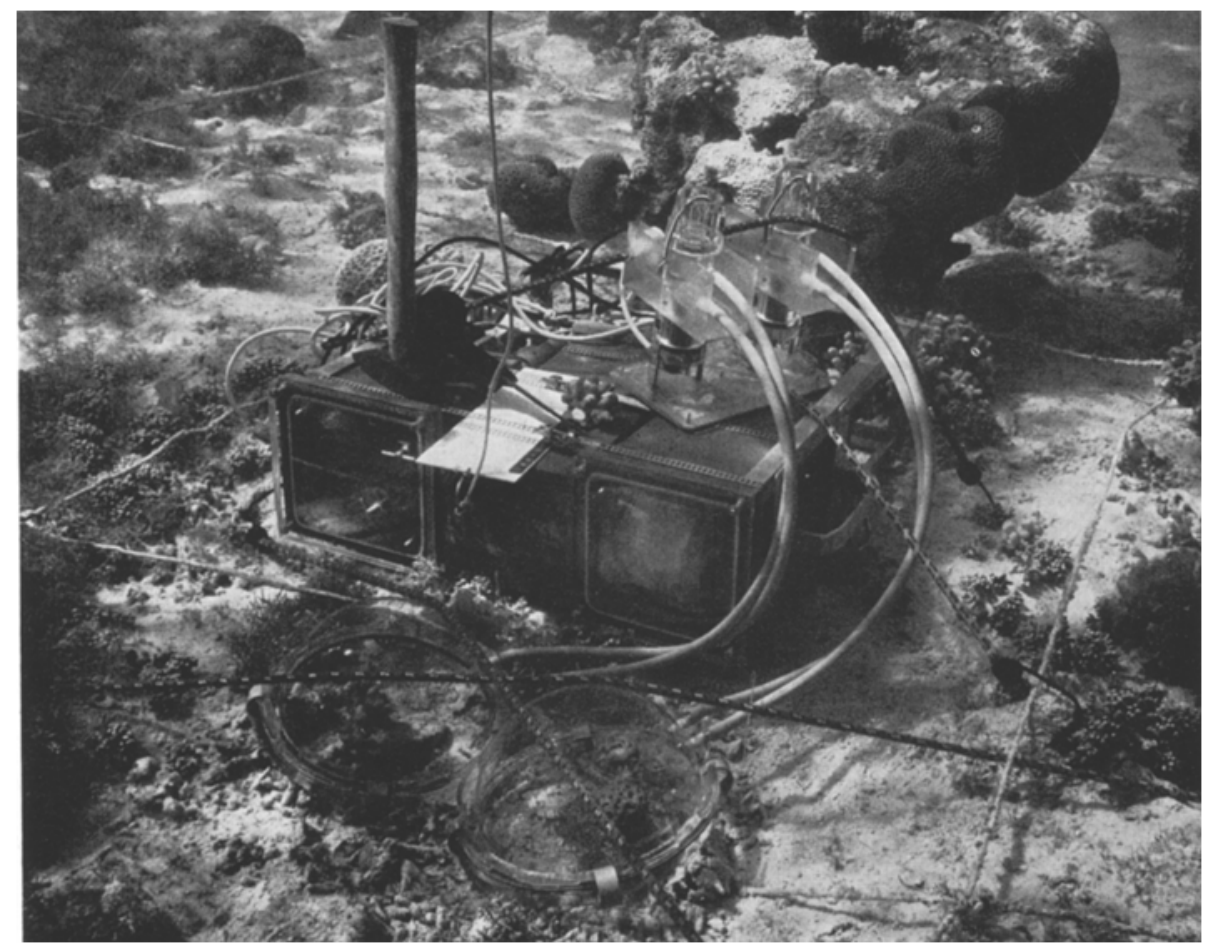

Fig. 5: Underwater oxygen recording device in the reef lagoon $(\mathrm{L}-1)$. The bell jars, containing Favia and Stylophora are connected to the circulation pump on top of the pressure-proof unit

Even without an intensive analysis (to be published later) the given data show the seasonal fluctuations in the test area L-1 during the winter period 1975 to 1976. At the beginning of the year the algal vegetation appears in different successions, abundances and dominances. This process is interrupted when the phytal disappears, in several steps, in springtime and in summer because of different biotic and abiotic conditions. These fluctuations in population dynamics lead to fundamental changes in living conditions of mobile fauna. Here the molluscs and echinoderms serve as good 
examples. Some soft corals too, like xeniids, and some stony corals, mainly Stylophora pistillata, are subjected to similar seasonal fluctuations within the same period, partly characterized by the disappearance of their colonies, partly by recolonization or new settling of colonies due to the preceding breeding season.

\section{Measurement of coelenterate respiration and productivity}

Daily measurements in the lagoon and in the fore-reef showed pronounced differences between the two areas both in oxygen and temperature conditions. In February $\mathrm{O}_{2}$ content in the lagoon ranged between $8.3-13.0 \mathrm{mg} / \mathrm{l}$ and temperature between $15^{\circ} \mathrm{C}$ at night to $23^{\circ} \mathrm{C}$ at noon (Fig. 6b). In the fore-reef $\mathrm{O}_{2}$ concentration ranged between $8.2-8.7 \mathrm{mg} / \mathrm{l}$ and temperature between $21.5 \pm 0.3^{\circ} \mathrm{C}$.

Below $5 \mathrm{~m}$ depth the visibility during the experiments was up to $40 \mathrm{~m}$. Maximal penetrating radiant energy occurred at $500 \mathrm{~nm}$ which is close to the maximal $\mathrm{O}_{2}$ response of the symbiotic dinoflagellates $(440 \mathrm{~nm}$, Halldal, 1968); a maximal penetrating radiant energy in shallow water of 1 to $5 \mathrm{~m}$ could be observed at $570 \mathrm{~nm}$. The light intensity at noon below the surface of $64 \mathrm{~mW} / \mathrm{cm}^{2}$ was reduced to $6.6 \mathrm{~mW} / \mathrm{cm}^{2}$ at $40 \mathrm{~m}$ depth. Since there is an almost constant compensation point (at 0.3 to 1.0 $\mathrm{mW} / \mathrm{cm}^{2}$ ), different daily photosynthesis duration become evident by comparing individuals at different depths (Fig. 6a, c-f).

Table 2

Mean values of respiration and productivity in several species from 1-40 m depth

\begin{tabular}{|lcccc|}
\hline Species & $\begin{array}{c}\text { Respiration } \\
(\mathrm{mg} \mathrm{O} / \mathrm{g} / 24 \mathrm{~h})\end{array}$ & $\begin{array}{c}\mathrm{O}_{2} \text { production } \\
(\mathrm{mg} \mathrm{O} / \mathrm{g} / 24 \mathrm{~h})\end{array}$ & $\begin{array}{c}\mathrm{O}_{2} \text { surplus } \\
\left(\mathrm{mg} \mathrm{O}_{2} / \mathrm{g} / 24\right.\end{array}$ & $\begin{array}{c}\mathrm{P} / \mathrm{R} \\
\text { rate }\end{array}$ \\
\hline Millepora dichotoma & 70 & 81 & 11 & 1.2 \\
Cassiopeia andromeda & 64 & 93 & 29 & 1.5 \\
Palythoa mammillata & 13 & 15 & 2 & 1.2 \\
Litbophyton arboreum & 72 & 75 & 3 & 1.0 \\
Heteroxenia gbardaqensis & 62 & 75 & 13 & 1.2 \\
Heteroxenia fuscescens & 68 & 72 & 4 & 1.1 \\
Xenia macrospiculata & 60 & 72 & 12 & 1.2 \\
Fungia scutaria & 22 & 31 & 9 & 1.4 \\
Acropora variabilis & 81 & 99 & 18 & 1.2 \\
Stylophora pistillata & 69 & 88 & 19 & 1.3 \\
Favia pallida & 24 & 30 & 6 & 1.2 \\
Goniastrea pectinata & 56 & 60 & 4 & 1.1 \\
\hline
\end{tabular}

The average respiration rate of a given species increases $50-100 \%$ if specimens from $1 \mathrm{~m}$ water depth are compared with specimens at $5 \mathrm{~m}$ depth or more. Individuals which were growing close to their deepest distribution range revealed a decrease in $\mathrm{O}_{2}$ consumption of about $10-20 \%$. In the first hours of the dark period all animals consumed more $\mathrm{O}_{2}$ by $20-30 \%$ than in the following night hours. Therefore, the calculated $24 \mathrm{~h} \mathrm{O}_{2}$ uptake had to be summed up using the low consumption values of 


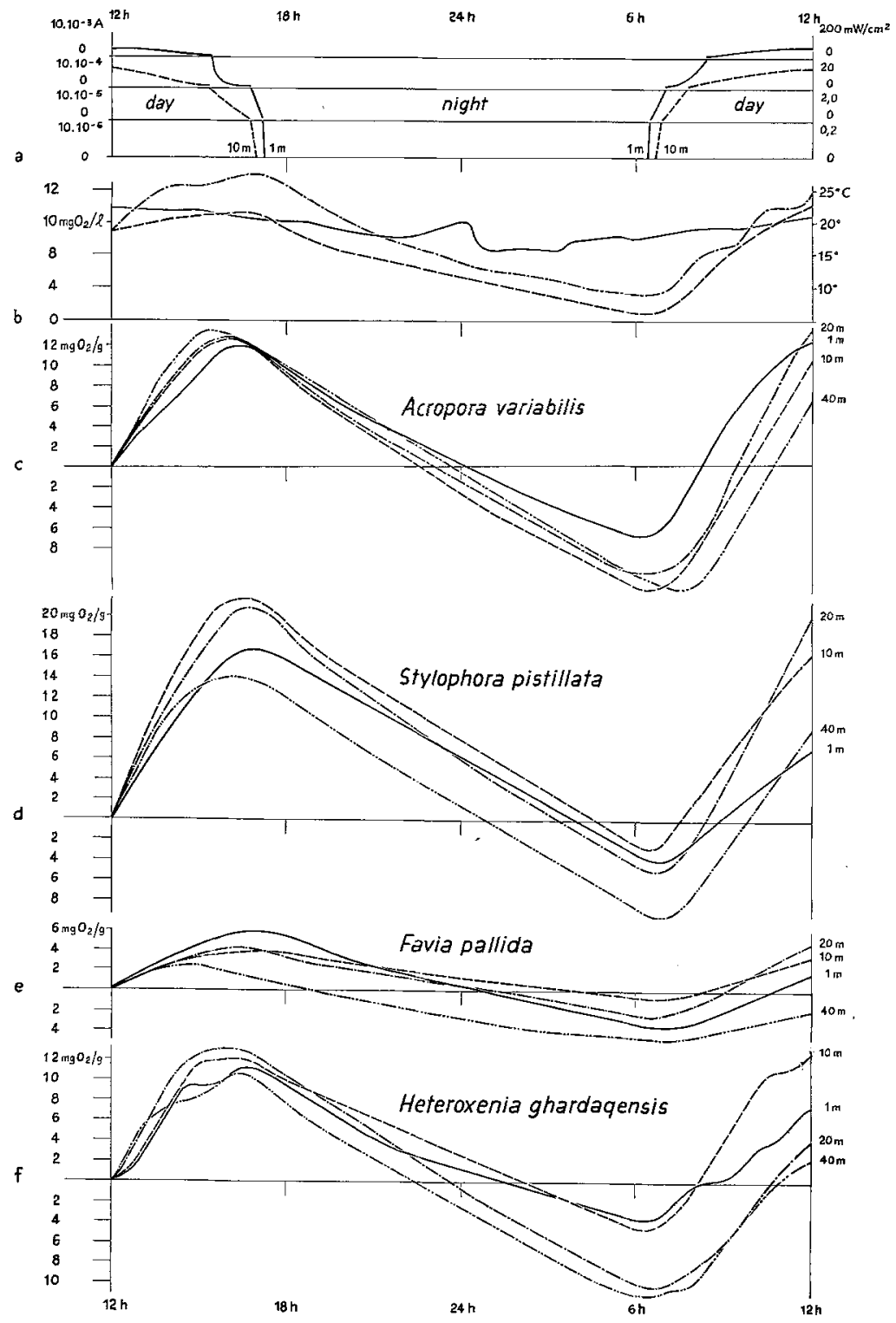

Fig. 6: Recordings of light, temperature and oxygen from noon to noon $(24 \mathrm{~h})$. a Daily light oscillation at $1 \mathrm{~m}$ and $10 \mathrm{~m}$ depth. $b$ Original record of temperature $(\mathrm{t})$ and change in oxygen content (mg O $/ 1 / 1$ ) in Stylophora (1) and Xenia (2) at $1 \mathrm{~m}$ depth (February, 26-27, 1976). $c$ Oxygen production and respiration in Acropora variabilis, $d$ in Stylophora pistillata, $e$ in Favia pallida, and $f$ in Heteroxenia ghardaquensis at different depths (referred to $1 \mathrm{~g}$ dry weight) 
the night hours and those of the day time when consumption increases considerably. The reasons for this respiration phenomenon seems to be the high level of carbohydrates which is available during the period of photosynthesis. Acropora, Millepora and Stylophora showed the highest respiration rates (per unit dry weight); the lowest ones were Favia and Palythoa. $\mathrm{O}_{2}$ production exceeded consumption in all species containing zooxanthellae (Table 2). The relative surplus of a species at $1 \mathrm{~m}$ depth was normally higher than at medium depths; it was slightly reduced at the deepest range of its occurrence. The $\mathrm{O}_{2}$ surplus per unit dry weight of individuals at $5 \mathrm{~m}$ depth and below was higher than in $1 \mathrm{~m}$ depth.

Concerning oxygen surplus, Cassiopeia, Stylophora and Acropora are among the most productive species whereas Favia, Goniastrea, Litbophyton and Palythoa are the least productive ones. By comparing $P / R$ ratio values, the range in species is slightly changed. Cassiopeia is followed by Fungia and Stylophora, the lowest values are found in Goniastrea, Heteroxenia fuscescens and Lithopbyton. The latter two alcyonarians may produce more oxygen when undisturbed. In many experiments specimens remained contracted after being chiseled off which may cause shading effects by dyes and spicules on the zooxanthellae.

In the morning at saturation light values of $2-10 \mathrm{~mW} / \mathrm{cm}^{2}$ there was the steepest increase in $\mathrm{O}_{2}$ followed by a steady decrease in productivity to the evening compensation point (Fig. $6 \mathrm{c}-\mathrm{f}$ ). Because there is no second production maximum in the afternoon, the decrease may be caused not by photoinhibition in the strong noon light, but by metabolic products or internal rhythms. The xeniids showed a stepwise increase in oxygen output as it is demonstrated in Figures $7 b+f$. The short interruptions in production occurred in the time of contraction of the colonies and may be the result of shading of the zooxanthellae and reduced water exchange caused by locking the gastral cavity for these short periods.

The species investigated produced a surplus of oxygen in a $24 \mathrm{~h}$ cycle, i. e. a surplus of fixed carbon in the poor light conditions of wintertime even down to the deepest range of occurrence. In the summertime owing to increased light intensities and prolonged insolation time a considerably increased production could result.

The method of measuring in closed systems seems to include errors in photosynthetic productivity of accumulated metabolic products. In parallel experiments on Anemonia sulcata (Svoboda, in preparation), in which one specimen was in a closed bell jar for $24 \mathrm{~h}$ and the other one in a bell jar rinsed every $3 \mathrm{~h}$, no differences in productivity and consumption could be found.

The low respiration and productivity of individuals at $1 \mathrm{~m}$ depth may be caused by photosynthetic inhibition at high levels of light intensity or by stress from temperature changes, sedimentation and erosion. The high productivity down to $40 \mathrm{~m}$ depth is due to the high transparency of the water, the increase of zooanthellae in coelenterate tissues with increasing depths (Drew, 1972; Svoboda, 1973) and a compensating decrease in respiration. A similar daily rhythm as in $\mathrm{O}_{2}$ production is also found in the calcification rate of hermatypic corals (Muscatine, pers. comm.).

Further productivity investigations in the Gulf of Aqaba are planned in order to analyse the effect of daily insolation duration and to obtain information on productivity of coelenterates per units of area especially from the extended slopes of the fore- 
reef. Such data may serve to prevent overfishing and destruction of the long term balance of these reefs in the future.

Acknowledgements. We gratefully acknowledge financial assistance received from the Deutsche Forschungsgemeinschaft and to the Austrian Fonds zur Förderung der wissenschaftlichen Forschung, grant 1302. Thanks are also extended to Dr. A. Badran and Dr. N. Hulings, University of Jordan, for their hospitality at the Marine Science Station Aqaba; to M. Mastaller and F. Nobbe for samples and observations; to M. Mastaller for translating this manuscript; and to $\mathrm{F}$. Theissen for carefully preparing illustrations.

\section{LITERATURE CITED}

Drew, E. A., 1972. The biology of alga-invertebrate symbiosis. II. Density of symbiotic algal cells in a number of hermatypic hard corals and alcyonarians from various depths. J. exp. mar. Biol. Ecol. 9, 71-75.

Franzisket, L., 1969. The ratio of photosynthesis to respiration of reef building corals during a 24 hour period. Forma functio 1, 153-158.

Gohar, H. A. F., 1940. Studies on the Xeniidae of the Red Sea. Publs. mar. biol. Stn. Ghardaqa 2, 25-118.

Halldal, P., 1968. Photosynthetic capacities and photosynthetic action spectra of endozoic algae of the massive coral Favia. Biol. Bull. mar. biol. Lab., Woods Hole 134, 411-424.

Johannes, R. E., Coles, S. L. \& Kuenzel, N. T., 1970. The role of zooplankton in the nutrition of scleractinian corals. Limnol. Oceanogr. 15, 579-586.

Kanwisher, J. W. \& Wainwright, S. A., 1967. Oxygen balance in some reef corals. Biol. Bull. mar. biol. Lab., Woods Hole 133, 378-390.

Lewis, D. H. \& Smith, D. C., 1971. The autotrophic nutrition of symbiotic marine coelenterates with special reference to hermatypic corals. I. Movement of photosynthetic products between the symbionts. Proc. R. Soc. Lond. (B) 178, 111-129.

Mergner, H. \& Schuhmacher, H., 1974. Morphologie, Ókologie und Zonierung von Korallenriffen bei Aqaba (Golf von Aqaba, Rotes Meer). Helgoländer wiss. Meeresunters. 26, $238-358$.

Muscatine, L. \& Hand, C., 1958. Direct evidence for the transfer of materials from symbiotic algae to the tissues of coelenterates. Proc. natn. Acad. Sci. U.S.A. 44, 1259-1263.

Odum, H. T. \& Odum, E. P., 1955. Trophic structure and productivity of a windward coral reef community on Eniwetok Atoll. Ecol. Monogr. 25, 291-320.

Roffmann, B., 1968. Patterns of oxygen exchange in some Pacific corals. Comp. Biochem. Physiol. 27, 405-418.

Svoboda, A., 1973. Beitrag zur Okologie, Biometrie und Systematik der mediterranen Aglaophenia-Arten (Hydroidea). Diss., Univ. Wien, 158 pp.

First author's address: Prof. Dr. H. Mergner

Lehrstuhl für Spezielle Zoologie

Ruhr-Universität Bochum

D-4630 Bochum 1

Federal Republic of Germany 